\title{
Cerebral lipogranuloma
}

\section{A penetrating traumatic brain injury}

Manuel Hagen, MD, Roland Coras, MD, Tobias Engelhorn, MD, Stefan Schwab, MD, and Frank Seifert, MD

Neurology ${ }^{\circledR}$ 2020;95:1019-1020. doi:10.1212/WNL.0000000000011071

Ten years ago, a 57-year-old man fell into a full oilcan, penetrating the straight spout suborbital into the right frontal lobe (figure, A). Two years later, he developed symptomatic epilepsy. A cranial MRI showed extensive edema formation (figure, B) and pathologic contrast enhancement (figure, C). In a neurosurgical biopsy, multiple granulomas around small oil droplets appeared. Histopathologic analysis revealed a chronic meningoencephalitis with granulomas and giant cells congruent with a foreign body reaction (figure, D-F).

Lipogranuloma is a rare inflammatory foreign body reaction to exogenous poorly resorbable lipid/oil-like substances. ${ }^{1}$ Under immunosuppressive therapy with methylprednisolone, ${ }^{2}$ seizure frequency has declined to 1 focal seizure per month.

Figure Chronic meningoencephalitis with lipogranuloma after traumatic brain injury
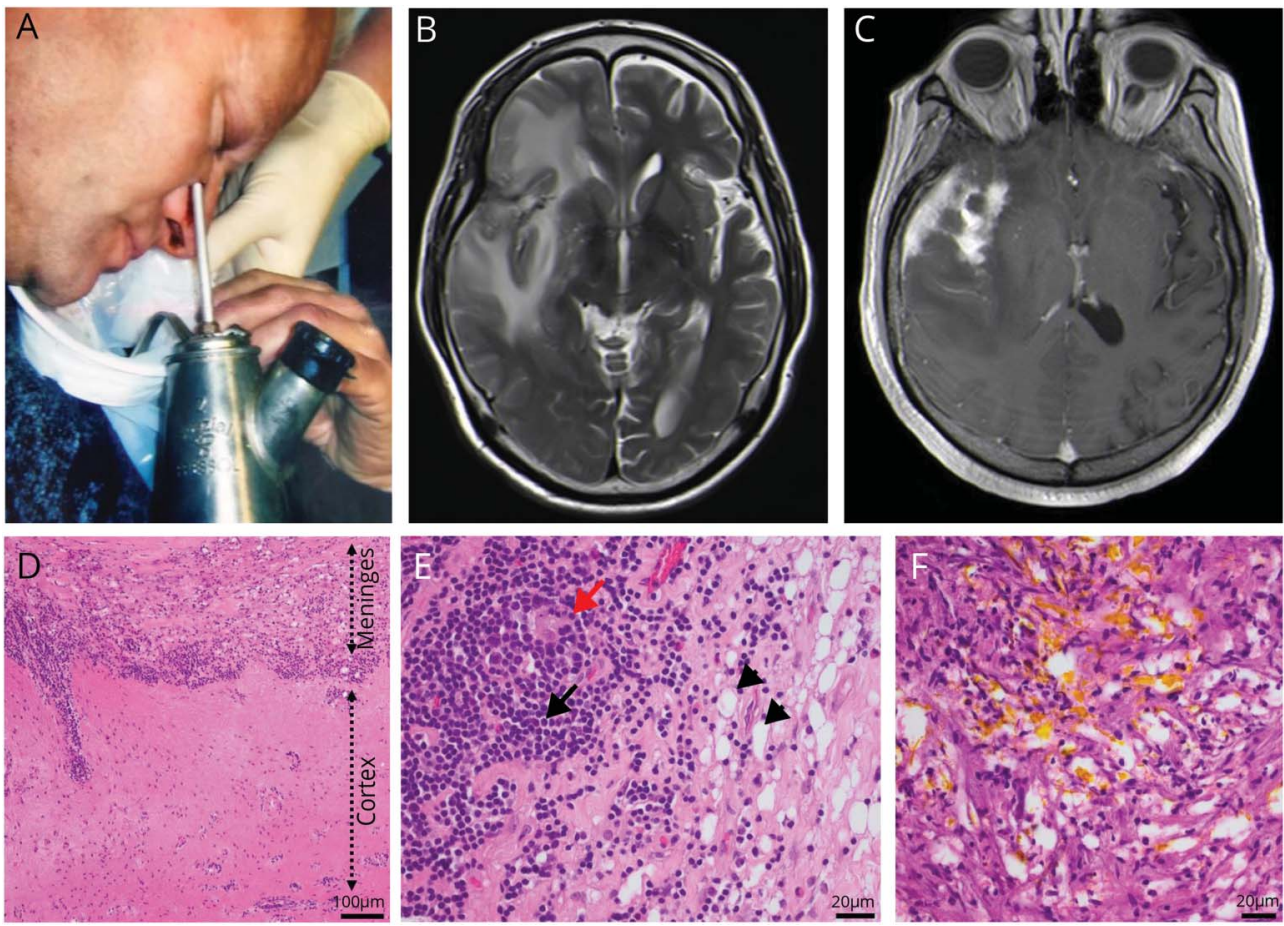

(A) Traumatic brain injury. (B) MRI demonstrates extensive edema formation. (C) Pathologic contrast enhancement. (D) Chronic meningoencephalitis. (E) Lymphomonocytic cells (black arrow) and single multinucleated giant cells (red arrow) in close association to a sclerotic stroma with numerous lipid vacuoles (arrowheads). (F) Hematoxylin \& eosin staining of vacuolated spaces with yellowish oil depositions.

\section{Correspondence}

Dr. Hagen

manuel.hagen@

uk-erlangen.de 


\section{Study funding}

No targeted funding reported.

\section{Disclosure}

The authors report no disclosures relevant to the manuscript. Go to Neurology.org/N for full disclosures.

Appendix Authors

\begin{tabular}{lll}
\hline Name & Location & Contribution \\
\hline $\begin{array}{l}\text { Manuel } \\
\text { Hagen, MD }\end{array}$ & $\begin{array}{l}\text { University Hospital } \\
\text { Erlangen, Germany }\end{array}$ & $\begin{array}{l}\text { Clinical care, drafting and } \\
\text { revision of manuscript }\end{array}$ \\
\hline $\begin{array}{l}\text { Roland } \\
\text { Coras, MD }\end{array}$ & University Hospital & $\begin{array}{l}\text { Clinical care, histologic analysis, } \\
\text { revision for intellectual content }\end{array}$ \\
\hline
\end{tabular}

Appendix (continued)

\begin{tabular}{lll}
\hline Name & Location & Contribution \\
\hline $\begin{array}{l}\text { Tobias } \\
\text { Engelhorn, } \\
\text { MD }\end{array}$ & $\begin{array}{l}\text { University Hospital } \\
\text { Erlangen, Germany }\end{array}$ & $\begin{array}{l}\text { Clinical care, MRI analysis, } \\
\text { revision for intellectual content }\end{array}$ \\
\hline $\begin{array}{l}\text { Stefan } \\
\text { Schwab, MD }\end{array}$ & University Hospital & $\begin{array}{l}\text { Clinical care, revision for } \\
\text { intellectual content }\end{array}$ \\
\hline $\begin{array}{l}\text { Frank } \\
\text { Seifert, MD }\end{array}$ & University Hospital & $\begin{array}{l}\text { Clinical care, editing and } \\
\text { finalizing the manuscript }\end{array}$ \\
\hline & & \\
& & \\
Referen, Germany & \\
1. & $\begin{array}{l}\text { Zhang F, Chen Y. Lipogranuloma after facial cosmetic procedures. Oral Surg Oral } \\
\text { Med Oral Pathol Oral Radiol 2017;123:e123-e132. } \\
\text { Seo JW, Sa HS. Periorbital lipogranuloma following facial autologous fat injections: }\end{array}$ \\
non-surgical treatment. Aesthet Plast Surg 2015;39:946-952.
\end{tabular}

\section{Subspecialty Alerts by E-mail!}

Customize your online journal experience by signing up for e-mail alerts related to your subspecialty or area of interest. Access this free service by clicking on the "My Alerts" link on the home page. An extensive list of subspecialties, methods, and study design choices will be available for you to choose from-allowing you priority alerts to cutting-edge research in your field!

\section{Get NeuroReady!}

Preparing for the neurology boards? Up for recertification? Or just looking for a comprehensive review and update in neurology? Get ready with the AAN's convenient online courses—now with new names! Choose from NeuroReady: Board Prep Edition or NeuroReady: Continuing Certification Edition and get ready to review, self-assess, and succeed. Visit AAN.com/NeuroReady.

\section{Neurology ${ }^{\circledast}$ Online CME Program}

Earn CME while reading Neurology. This program is available only to online Neurology subscribers. Read the articles marked CME, go to Neurology.org, and click on CME. This will provide all of the information necessary to get started. The American Academy of Neurology (AAN) is accredited by the Accreditation Council for Continuing Medical Education (ACCME) to sponsor continuing medical education for physicians. Neurology is planned and produced in accordance with the ACCME Essentials. For more information, contact AAN Member Services at 800-879-1960. 


\section{Neurology}

\section{Cerebral lipogranuloma: A penetrating traumatic brain injury \\ Manuel Hagen, Roland Coras, Tobias Engelhorn, et al. \\ Neurology 2020;95;1019-1020 Published Online before print October 14, 2020 \\ DOI 10.1212/WNL.0000000000011071}

This information is current as of October 14, 2020

Updated Information \&

Services

References

Subspecialty Collections

Permissions \& Licensing

Reprints including high resolution figures, can be found at: http://n.neurology.org/content/95/22/1019.full

This article cites 2 articles, 0 of which you can access for free at: http://n.neurology.org/content/95/22/1019.full\#ref-list-1

This article, along with others on similar topics, appears in the following collection(s):

All Clinical Neurology

http://n.neurology.org/cgi/collection/all_clinical_neurology

All Epilepsy/Seizures

http://n.neurology.org/cgi/collection/all_epilepsy_seizures

MRI

http://n.neurology.org/cgi/collection/mri

Partial seizures

http://n.neurology.org/cgi/collection/partial_seizures

Information about reproducing this article in parts (figures,tables) or in its entirety can be found online at:

http://www.neurology.org/about/about_the_journal\#permissions

Information about ordering reprints can be found online:

http://n.neurology.org/subscribers/advertise

Neurology ${ }^{\circledR}$ is the official journal of the American Academy of Neurology. Published continuously since 1951, it is now a weekly with 48 issues per year. Copyright (? 2020 American Academy of Neurology. All rights reserved. Print ISSN: 0028-3878. Online ISSN: 1526-632X.

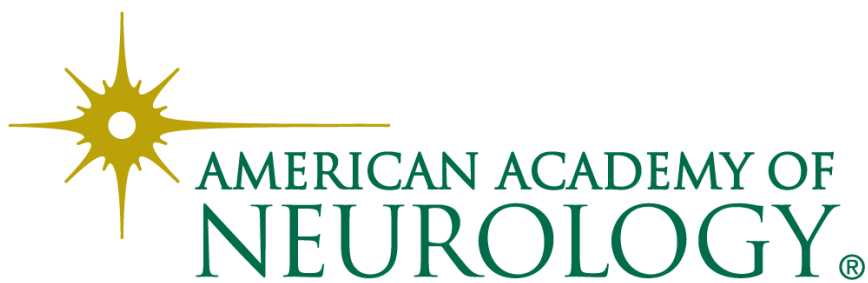

